\title{
Enterprise and Innovation
}

\section{Insiders and the Law: The Impact of Regulatory Change on Insider Trading}

\section{Aaron Gilbert, Alireza Tourani-Rad and Tomasz Piotr Wisniewski}

\section{Research Paper Series}

Faculty of Business ISSN Number 1176-1997

Paper 14-2004 
ISSN 1176-1997

\section{INSIDERS AND THE LAW: THE IMPACT OF REgULATORY CHANGE ON INSIDER TRADING}

\section{Aaron Gilbert, Alireza Tourani-Rad and Tomasz Piotr Wisniewski}

2004 @ - Copyright of the Author(s)

Alireza Tourani-Rad*

Professor of Finance

Department of Finance

Faculty of Business

Auckland University of

Technology

Private Bag 92006

Auckland 1020

New Zealand
Aaron Gilbert

Department of Finance Faculty of Business Auckland

University of Technology

Private Bag 92006

Auckland 1020

New Zealand

Tel: +64-(0)9-917-9999 x5338

e-mail: aaron.gilbert@aut.ac.nz
Tomasz Wisniewski

Department of Finance Faculty

of Business Auckland

University of Technology

Private Bag 92006

Auckland 1020

New Zealand

Tel: +64-(0)9-917-9999 x5393

e-mail: tomasz.wisniewski@aut.ac.nz

Tel: +64-(0)9-917-9999 x5336

e-mail: tourani@aut.ac.nz

*Author for Correspondence

The opinions and views expressed in this paper are those of the author(s) and not necessarily those of AUT of the General Editor or Review Panel of Enterprise and Innovation. 


\section{AUT AUTHORS}

\section{AARON GILBERT}

Aaron is currently a student at Auckland University of Technology doing a PhD focused on insider trading. He has published in the University of Auckland Business Review and the Pacific Basin Finance Journal and has presented at the 16th Australasian Banking and Finance Conference 2003 and the Doctoral Students Seminar held at the European Financial Management Association Meetings 2004.

\section{ALIREZA TOURANI-RAD}

Dr. Alireza Tourani-Rad is a Professor in Finance and head of the Finance Research Centre. His previous positions include Professor of Finance at the University of Waikato Management School and Associate Professor at Masstricht University in the Netherlands. Dr. Tourani-Rad specialises in the corporate and international finance areas. He completed his Ph.D. at the Free University of Brussels and his Masters' degree at the Catholic University of Leuven in Belgium. He was Executive Vice President of the European Financial Management Association and Secretary of the Limburg Institute of Financial Economics. He has held visiting positions at a number of leading European Universities. He has published extensively in international journals on aspects of European financial markets and completed works on PacificBasin financial markets.

\section{TOMASZ WISNIEWSKI}

Tomasz Piotr Wisniewski is a Lecturer in Finance at the Auckland University of Technology. Previously he worked as a Postgraduate Research Fellow at the European University Viadrina in Germany. His main areas of interest are asset pricing and regulation of insider trading. His recent papers have been accepted for publication in the International Review of Law and Economics, Economic Systems and Finance Letters. 


\section{Research Paper Joint Publication}

This paper is jointly published in Postgraduate Research Programme "Capital Markets and Finance in the Enlarged Europe", European University Viadrina Frankfurt (Oder), Germany.

Copies of other papers in the Postgraduate Research Programme series are archived at the website:

http://www.wiwi.euv-frankfurt-o.de/gk-wiwi/en/eng_wps.html

where they can be downloaded as Adobe Acrobat (PDF) files. 


\title{
INSIDERS AND THE LAW: THE IMPACT OF REGULATORY CHANGE ON INSIDER TRADING
}

\begin{abstract}
The impact of regulations in minimizing the detrimental effects of insider trading is unsettled. In this paper, we investigate the impact of the introduction of the Securities Market Amendment Act 2002 in New Zealand on several aspects of the market. After examining a sample of companies listed before and after the new laws introduction, we find strong evidence of a reduction in the cost of capital, bid-ask spreads and volatility accompanied by increases in liquidity, all as predicted. We conclude that the change in regulations has had a positive impact on the market.
\end{abstract}

JEL Codes : G38, G14, C33

Keywords: Insider Trading, Market Microstructure, Regulation, Cost of Capital 


\section{INTRODUCTION}

The merits of regulating insider trading have been the subject of vigorous debate in the finance literature since Manne (1966) suggested unfettered insider trading should be encouraged. The basis of the debate has been the costs and benefits of insider trading on the market as a whole. Manne (1966) and others have argued that insider trading has a beneficial effect on the price efficiency of a market and by extension the efficiency of its resource allocation and investment decision making (Kyle, 1985; Leland, 1992). The contention from those favouring regulation however, is that insider trading damages investor confidence in the market and as such has serious effects on the stock market including increased bid ask spreads, cost of capital and market volatility in addition to reduced liquidity. While the academic debate on deregulation is still unsettled, it appears that insider trading has been accepted by most countries as a necessary evil. However, rather than the unencumbered insider trading envisioned by Manne (1966), it has been regulated in over $80 \%$ of countries with capital markets (Bhattacharya and Daouk, 2002). The regulations seek to strike a balance between allowing insiders enough opportunity to trade to allow the market to receive the benefits of their superior pricing ability while limiting the harm to ordinary shareholders from insiders' use of confidential information. The literature to date has failed to conclusively show how successful the attempts to regulate a balance have been in controlling insider trading.

\section{Impact of Insider Trading}

The issue of insider trading has been widely addressed with much focus on the fact that insider trading is inequitable for outside investors who lack access to the same information as insiders. Numerous studies in a number of markets around the world show almost uniformly that insiders earn positive abnormal returns ${ }^{1}$. These profits however, are earned at the expense of uniformed investors who ultimately are those trading against insiders. Ausbel (1990) concludes that the presence of insiders' in a market causes other investors to lose confidence in the market which has flow-oneffects for market efficiency.

One of the most noticeable effects of insider trading is its influence on bid-ask spreads. Insiders due to their access to preferential information hold a significant 
advantage over the rest of the market allowing them to expropriate sizeable trading profits. This poses a significant risk to other investors in the market, a risk that increases with the prevalence of insiders in the market. To counter this risk, market makers increase the bid-ask spreads to offset the expected losses from trading against insiders (Kyle, 1985; Glosten and Milgrom, 1985; Copeland and Galai, 1988). As a result, firms and markets where insider trading is pervasive are subject to increased spreads to accommodate the greater informational asymmetry risk. Chung and Charoenwong (1998) examined the impact of insider trading intensity on the bid ask spreads by comparing spreads on insider trading days to other days. They concluded that without disclosure the market was unable to determine when an insider trades. As a result market makers maintained larger spreads for stocks were the incidence of insider trading was greater and at times of abnormally high volume to compensate for the extra information asymmetry in those companies.

The effect on spreads is compounded by the effect insider trading has on market liquidity. Liquidity is a key determinant of bid-asks and the reduction in liquidity as a result of insider trading increases the spreads even further. Ausbel (1990) suggests that when outsiders expect to be taken advantage of, they are likely to reduce their investment in the market from the start. This contention is supported by Bernhadt, Hollifield and Hughson (1995) who argued that investors are likely to make investment decisions on the basis of the amount of information asymmetry, seeking projects with a lower risk of expropriation by insiders. They point out that this can lead to market distortions with investors selecting projects based on the risk of exploitation rather than the economic merits of projects. Fishman and Hagerty (1995), Leland (1992) and Repullo (1999) in their theoretical models all predict a decrease in liquidity in situations where insider trading is more intense.

The reduction in liquidity can also be linked to a decrease in market depth. This lack of depth means that the market lacks the ability to soak up significant volumes of shares traded without impacting on the price due to limited demand and supply for shares. Kyle (1985), Leland (1992) and Repullo (1999) predict that the presence of insiders reduces the depth of the market and thereby increases the volatility that investors face. This is significant in that it increases the risk for investors 
that they will not be able to exit their investment or the market without facing a large financial penalty.

Insider trading has also been linked to increases in the cost of capital. This is a result of a number of factors such as the need to cover the increased transaction costs caused by the larger bid ask spreads, the increased risk of being unable to sell an investment in a timely fashion without a large financial penalty and decline in corporate governance (Bhattacharya and Daouk, 2002). This link was established empirically by Bhattacharya and Daouk (2002) who examined the impact of introducing insider trading laws and the first enforcement on four proxies for the cost of capital across 103 countries. They found that a significant decrease occurred following the first successful enforcement of insider trading sanctions, although there was no significant reaction to the introduction of the laws.

Insider trading has been both theoretically and empirically shown to have serious outcomes for capital markets. Increased spreads, increased volatility and decreased liquidity all reduce the ability of the market to fulfil its function with flow-oneffects for resource allocation. The increased cost of capital for companies introduces further distortions, such as forcing companies to reject efficient projects. While both the harm and the beneficial effects of insider trading have been established, the impact that regulation has is still the subject some controversy.

\section{The Role of Regulation}

The role of regulation and laws should be to minimise the harm from insider trading. As has been argued, insider trading causes distortions in capital markets such as inefficient resource allocation, mispricing and lost opportunities for investment. However, the evidence on the efficacy of regulation in this respect is mixed. Several papers have examined the impact of changes in insider trading laws on the profitability and volume of insider trading. Jaffe (1974) analysed the impact that three major cases that occurred in the US in the 1960's had on insider trading. The author argued that the three cases all either extended the reach of the law or demonstrated the will to enforce the legislation which had not been enforced since its enactment in 1934. Interestingly, the paper was unable to find a significant decrease in profitability or volume before and after either the cases individually or collectively. Jaffe 
suggested that while the law changes made the regime more restrictive they were still primarily aimed at the most flagrant cases and therefore did not have a major impact. Seyhun (1992) conducted examination of the effects of legislative changes and case law during the 1980's, a period in which the SEC focused its enforcement efforts on insider trading and the penalties for the exploitation of material non-public information were increased markedly. Looking at the profitability and volume he concluded that the regulatory changes had been ineffective in controlling insider trading. Banerjee and Ekard (2001) examine insider trading prior to mergers between 1897 and 1903 and find that the patterns and price run-ups are similar to those found prior to recent mergers. They conclude that insider trading laws have been ineffective in preventing insider trading although they do suggest this maybe the result of a growth in information specialists supplanting pure insiders.

By contrast, several recent studies have concluded that both amendments to and the introduction of insider trading laws have impacted on the market. Bhattacharya and Daouk (2002) employed a sample of over 100 countries to examine the impact on the cost of capital of a countries enactment and the first successful enforcement of insider trading laws. They concluded that while the enactment of the laws did not have a significant effect, the first enforcement resulted in a marked decrease in the cost of capital regardless of the proxy used to measure it. Bushman, Piotroski and Smith (2003) employed the same sample to examine the impact of insider trading on analyst following, arguing that the presence of insiders crowds out analysts resulting in reduced coverage. They concluded that for developed markets the first introduction of insider trading laws sees a significant increase in analyst following while emerging markets require the laws to be successfully enforced before any benefit materialises. This was supported at the firmlevel by Gilbert, Tourani-Rad and Wisneiwski (2004) who found that even after controlling for other effects, higher firm-level insider trading resulted in fewer analysts following a company.

Garfinkel (1997) looked specifically at insider trading around earnings announcements both before and after the introduction of the Insider Trading and Securities Fraud Enforcement Act (ITSFEA) of 1988. The author observed a marked change in the behaviour of insiders who went from trading prior to and in the same 
direction as the earnings surprise prior to the law change to trading after and against the direction of the shock afterwards. They also concluded that earnings announcements were more informative in the post change period suggesting less information trading before the announcement. This pattern has also been observed in other US studies such as Noe (1999) who looked at management earnings forecasts and Piotroski and Roulstone (2003) who concluded that after the introduction of the ITSFEA insiders were trading on their ability to predict accurately share prices in the long-term rather than upcoming announcements.

The evidence on the effects of regulatory change is mixed. Earlier studies that concentrated on profitability and volume of insider trading failed to find evidence of significant market adjustment. However, later studies that have examined other aspects such as the information used to trade, the timing of the trades, effect on the cost of capital and analyst following have noted significant changes. It may be that recent improvements in the technology available for detecting insider trading have had an impact on insider conduct or that regulations fail to prevent insider trading being profitable but do significantly impact other areas. Either way more research on additional markets is needed to clarify the role of regulations in controlling and minimising the detrimental consequences of insider trading. Evidence of the impact of regime changes is limited outside the US making the examination of other markets important in discounting the possibility that the US's long history of regulating insider trading may make its reaction unrepresentative of other markets.

\section{The New Zealand Situation}

The recent legislative changes to insider trading in New Zealand provide a good opportunity to add further evidence to the debate regarding the efficacy of regulations. Prior to 2002 insider trading was governed by the Securities Market Act 1988. There has been much commentary on this acts effectiveness based on anecdotal evidence. In particular, it has been argued the law was ineffective as it had failed to result in a successful prosecution despite being in effect for over a decade. This was further reinforced by several cases in the early 1990's which effectively weakened the enforcement mechanisms contained within the act ${ }^{2}$. The criticism appears to be justified in two major areas, the disclosure requirements set out in the act and the enforcement regime it established. 
The disclosure requirements in the act set out differing disclosure requirements based on the class of corporate insider. The problem however, was that the length of time between trade and disclosure was inversely related to the information hierarchy within in a firm as established in Seyhun (1998). Substantial shareholders, those holding more than $5 \%$ of the voting rights, were required to disclose details of their trades within 5 working days. Directors, on the other hand, were required to disclose their transactions only in the annual reports. This represents a minimum delay between the end of the financial year and the publication of the report of 3 months with an average delay between trade and disclosure of 9-10 months (Etebari, Tourani-Rad and Gilbert, 2003). Executives, those identified by Seyhun (1998) as having the best access to information were not required to disclose their transactions at all. Given the finding by Chung and Charoenwong (1998) that the market is unable to detect insider trading without disclosure, the long delays reduce the informational benefits to the market from insider trading considerably. According to the model of Huddart, Hughes and Levine (2001) the lack of timely disclosure makes insider trades more profitable both over time and on a per round basis. The findings of Etebari, et al. (2003) and Gilbert et al. (2004) support this by showing that the delay in disclosure in New Zealand between directors and large blockholders allowed directors to earn significantly larger abnormal returns. It also supports the perception that the laws were ineffective in minimising the harm from insider trading.

The second major area of concern was the enforcement mechanisms set out in the law. Rather than relying on a public enforcement regime such as is employed in the US and the UK, the Securities Market Act (1988) relied on private enforcement. The company in whom the trading took place and the other party to the trade were permitted to take a suit for insider trading. This placed the burden of proof on those with the least access to the information and expertise required to establish if illegal insider trading occurred. Compounding this was the fact that only the company was able to sue for punitive damages and private individuals were only able to recover the value of loss that they personally incurred, making it uneconomical to pursue a case. Companies have also proven reluctant to prosecute their own insiders even in high profile cases. 
In response to the ineffectiveness of the previous regime, the Securities Market Amendment Act (2002) was enacted and came into force on the 1 December 2002. This act has sort to address weaknesses in the old act with the most profound changes addressing the above deficiencies in the regulations. The new law requires that all corporate insiders; blockholders, directors and executives, disclose within 5 working days. The new act also gives the Securities Commission, the local securities watchdog, the ability to take over a company's right of action where it chooses not to sue. The combined effect of these changes should be a marked increase in the expected cost of insider trading as blatant breaches are more likely to be prosecuted and, at the same time, a reduction in the profitability of the insider trading due to the new disclosure laws.

The purpose of this paper is to examine these recent changes in insider trading legislation to see if they have had the expected impact on the market. This will also allow us to add further to the debate on the efficacy of regulations and regulatory changes in controlling insider trading and its negative implications. We examine the average level of four variables, dividend yield, bid ask spreads, liquidity and volatility, in the pre and post change periods to determine if the law changes have minimised the influence of the negative aspects of insider trading on the market. Using a sample of 85 companies listed on the New Zealand Stock Exchange (NZX) over the period 1996-2004 we examine the level of each variable in the two periods. We use a variety of testing methods including the matched pairs t-test, the Wilcoxon signed rank test, rolling regressions and fixed effect panel regressions to see if the variables experienced statistically significant changes in the expected directions. We find marked decreases over all the tests employed for the dividend yield (a proxy for cost of capital), bid ask spreads and volatility. We also see significant increases in the total value of traded shares in the post change period. The results give support to the hypothesis that the recent changes have had a beneficial impact on the market as a whole.

The rest of the paper is set out as follows. Section 2 contains information on the sample and variable construction along with the methodology employed. Section 3 presents the results of the testing while Section 4 presents the papers conclusions. 


\section{SAMPLE, VARIABLES AND METHOdOLOGY}

\section{Sample}

The sample employed in this study was drawn from companies that were listed on the New Zealand Exchange between January 1996 and March 2004. Only companies that survived over the entire period were considered to allow for a more accurate appraisal of the effect of the change in insider trading laws by eliminating potential fundamental changes in the composition of the sample. This resulted in a sample of 85 companies with 8416 firm-months worth of observations.

Data on volume, bid prices, ask prices, dividend yield and market capitalisation were obtained from Thompson Financials DataStream. Information on cross-listing dates was obtained from the Datex market announcements database.

To establish whether the change in regulation has had an impact on the market we performed an analysis of a number of microstructure aspects that have been both theoretically and empirically shown to be affected by insider trading. We examine the impact by studying these variables in two time periods, the pre-change period from January 1996 to December 2001 and the post-change period from December 2002 to March 2004. As the Securities Market Amendment Act 2002 spent most of 2002 working through the legislative process there is a possibility that the market may have anticipated the act given its main provisions were well established and widely known prior to enactment. For this reason January 2002 to November 2002 were examined separately to see if there was any evidence of the market reacting before the act came into power. The change period was also tested separately in the panel regressions, but in results not reported was shown to not be significant.

\section{Variables}

We examine the impact of the recent law changes on four variables to see whether the recent law has minimised the harm from insider trading in the local market. The first variable we examined is the dividend yield which we use to proxy for the firm level cost of capital. As noted in a number of studies the cost of capital is difficult to 
determine directly (Bhattacharya and Daouk, 2002; Bekaert and Harvey, 2000). For this reason proxies have been employed to examine the impact of differing events on the cost of capital. One of the proxies suitable for a firm-level examination of the cost of capital is the dividend yield. Bekaert and Harvey (2000) provide a detailed examination of the link between the cost of capital in general pricing models and dividends, but as was noted by Bhattacharya and Daouk (2002) a simple approximate way of calculating the cost of equity is simply to back it out of the constant growth dividend valuation model. They also point out that the dividend yields are easily observed and do not move much making them an excellent proxy for estimating the effect of a discrete change in the laws. Bekaert and Harvey (2000) also conclude that in the case of small samples, dividend yields are superior to the other method advocated by Henry (2000) of using realised returns as a proxy for cost of capital as returns are more variable. As a result, we employ dividend yields to examine the impact of the change in the law on the cost of capital. We measure the dividend yield as the annualised dividend yield.

The second variable examined was the bid-ask spread $(B A)$ defined as

$$
B A=\ln \left(\frac{(A s k-B i d)}{(A s k+B i d) / 2}\right)
$$

This definition is similar to that Chung and Charoenwong (1998) who examined the impact of insider trading on spreads. Unlike that paper however, we use closing bid and ask prices to measure the spread. Interday prices have been used in a number of papers examining the bid-ask spreads (Jain, 2002; Acker, Stalker and Tonks, 2002). Closing prices were used as they are more appropriate given the length of sample period being examined and due to the difficulty of obtaining intraday data in New Zealand. As was shown in Acker et al. (2002), interday closing prices are a reasonable estimator of the actual spread. We use the log transformation to reduce the skewness in the spreads.

Another variable examined was liquidity. A number of papers have asserted that insider trading reduces liquidity (Kyle, 1985; Glosten and Milgrom, 1985; Copeland and Galai, 1988; Ausbel, 1990; Leland, 1992; Repullo, 1999). If the new 
laws are effective, therefore, we would expect liquidity to improve. We measure liquidity by taking the dollar value of daily trading and dividing it by the market capitalisation to standardise the variable across companies. This measure was used by Jain (2002) and produces similar results to the average volume traded measure employed in Acker et al. (2002) and Chung and Charoenwong (1998).

The final variable inspected is the return variance of firms. Kyle (1985) argues that the presence of insider trading reduces the depth of a market, making it less liquid and prone to greater price movements. Less insider trading should therefore imply greater market depth and more liquidity resulting in less volatility over time. We define return variance as the natural log of the variance of the midpoint of spreads of the previous 30 days. As per Jain (2002) we use the midpoints to avoid any potential bias from the bid ask bounce. As variances are expected to follow a chi-square distribution and exhibit skewness we use a log transformation to allow reliable tstatistics to be obtained.

\section{Methodology}

To determine whether the recent law changes were effective we examined the level of each of the variables in the pre and post periods. To test this we use a variety of tests including the matched pairs t-test which examines whether the difference in the yearly means are significantly different from zero. We also use the Wilcoxon signed rank test to determine whether there has been a significant change in the mean. For this testing we compared the means on a yearly basis with the last 12 months of data following the change, April 2003 - March 2004. This was done to maintain the comparability of the samples and to allow the full effect of the changes to be examined without potential bias during the implementation period. Rolling regressions, regressing the last 100 observations against a constant were also employed. This was performed by taking an equally weighted average of each variables and regressing it against a constant to compute the estimate and two standard deviations. This was then plotted over time to provide a graphical representation of the regression estimate over time (Driffill and Sola, 1998). Finally, we employ fixed effect panel regressions on firm-month level data of each variable against a dummy variable that equals 1 in the months following the introduction of the new laws. These regressions also include several control variables, $M V$, defined as 
the natural log of the firms market capitalisation and CROSS which is a dummy variable that equals one for each month that a firm has a cross listing on another exchange. This is used to control for firms that are subjected to the laws of another exchange and therefore may already be subjected to tighter regulations. As a robustness check we employed the $F$ test to test the significance of group effects in each of the model specifications employed. We found uniformly that the fixed effect panel is superior compared to the restricted model. Further, the fixed model was preferred as it does not suffer from the omitted variable problem that can plague the random effect models (Hausman and Taylor, 1982; Chamerlain, 1978). As a specification test we also re-estimate our panel regressions using an adjustment for serial correlation in the errors. In particular, the regressions include a lagged error term from a two stage regression.

\section{Results}

To address the effectiveness of the new laws we examined four variables that have been predicted to be impacted by insider trading. If the new laws have been effective then the cost of insider trading should have increased. The new disclosure rules should ensure the market becomes informed more rapidly reducing ongoing profits to insiders as predicted by Huddart et al. (2001). The provision allowing the Securities Commission to prosecute insider trading should increase the likelihood of prosecutions against insiders. It would be expected therefore that there should be less information asymmetry in the market as well as reduced information driven insider trading. If the new laws are effective there should be a reduction in dividend yields, a sign of decreased cost of capital, decreased bid ask spreads and volatility as well as increased liquidity as the New Zealand market becomes seen as less risky.

\section{Descriptive Statistics}

Table 1 gives summary statistics based on firm-month data for the variables used. The BA spread has an arithmetic average of .0768 , or a spread of $7.68 \%$ of the price. This is significantly larger than the average spreads reported in the US (Chung and Charoenwong (1998) report 1.83\%) or the UK (Acker et al. (2002) report 2.3\%). This is likely due to the small size of the market with its resulting low liquidity. The table 
also shows that on average $.08 \%$ of a firms' market value is traded on a daily basis with an average of 143,000 shares traded. This variable however has a large standard deviation indicating that there is a large difference between the average shares traded of the most and least liquid companies on the New Zealand market. VAR had an average of .00033 , while DY had an average of .0575 . The latter value is higher compared to other markets due to the tendency of NZ companies to pay out larger dividends than companies elsewhere. The average firm market capitalisation over the sample period was just NZ\$91 million indicating that companies in New Zealand are much smaller than their counterparts in other developed markets ${ }^{3}$.

\begin{tabular}{cccccc}
\hline Variable & Mean & Std. Dev. & 1st Quartile & Median & 3rd Quartile \\
\hline BA & -3.5298 & 1.1757 & -4.4040 & -3.6877 & -2.8406 \\
VOL & 0.0008 & 0.0015 & 0.0001 & 0.0004 & 0.0009 \\
VAR & -8.0120 & 1.6738 & -8.8899 & -8.0588 & -7.0770 \\
DY & 0.0575 & 0.1188 & 0.0000 & 0.0348 & 0.0600 \\
MV & 4.5150 & 2.0434 & 3.0474 & 4.4581 & 5.8491 \\
\hline
\end{tabular}

Table 1: Descriptive Statistics

Note: $B A$ defined as the natural log of the monthly average of the daily ask price minus the bid price divided by the midpoint of the spreads. $V O L$ represents the firm's liquidity defined as the monthly average of the daily dollar value of trading divided by the market value of the company. $M V$ is the natural log of the firms market capitalization averaged for the calendar month. VAR represents the return volatility of the firm defined as the natural log of the variance of returns over the period $-30,0$, averaged over each calendar month. $D Y$ is defined as the monthly average of the annualised dividend yield. $M V$ is the log of the firms market capitalization averaged for the calendar month.

The sample cross correlations are presented in Table 2. Bid-ask spreads (BA) have significant negative relationships with VOL, MV, CROSS, and DY, indicating that lower spreads are associated with larger more liquid companies, as well as companies that are cross-listed on other markets. We also see lower spreads are associated with companies with higher dividend yields, likely a result of the higher rate of dividends that larger companies pay out. The positive relationship with VAR suggests that lower variance is associated with lower spreads. VAR has negative associations with $M V$, and $D Y$ implying that larger companies and companies with higher dividend yields have lower volatility of returns. Finally, we also see strong relationships in the predicted directions between POST and all key variables, BA (-) 
DY (-) VAR (-) and VOL (+). This lends some preliminary support to the hypothesis that the changes in law have had a positive impact on the market.

\begin{tabular}{|c|c|c|c|c|c|c|}
\hline & VOL & VAR & MV & CROSS & POST & DY \\
\hline \multirow[t]{2}{*}{$B A$} & -0.0572 & 0.2211 & -0.6949 & -0.0602 & -0.0731 & -0.0421 \\
\hline & (0.0344) & (0.0023) & $(0.0001)$ & (0.0311) & (0.0214) & (0.0609) \\
\hline \multirow[t]{2}{*}{$V O L$} & & -0.0116 & 0.0585 & -0.0003 & 0.0605 & -0.0146 \\
\hline & & (0.3974) & (0.0329) & (0.9818) & (0.0309) & (0.3121) \\
\hline \multirow[t]{2}{*}{$V A R$} & & & -0.3710 & 0.0543 & -0.0653 & -0.2874 \\
\hline & & & (0.0007) & $(0.1380)$ & $(0.0267)$ & (0.0013) \\
\hline \multirow[t]{2}{*}{$M V$} & & & & 0.2460 & 0.0174 & 0.1759 \\
\hline & & & & (0.0018) & $(0.2512)$ & (0.0037) \\
\hline \multirow[t]{2}{*}{ CROSS } & & & & & 0.0518 & 0.0124 \\
\hline & & & & & (0.0414) & (0.3744) \\
\hline \multirow[t]{2}{*}{ POST } & & & & & & -0.0798 \\
\hline & & & & & & $(0.0180)$ \\
\hline
\end{tabular}

Table 2: Sample Cross Correlations

Note: $p$-values are in parentheses. BA defined as the natural log of the monthly average of the daily ask price minus the bid price divided by the midpoint of the spreads. VOL represents the firms liquidity defined as the monthly average of the daily dollar value of trading divided by the market value of the company. VAR represents the return volatility of the firm and is defined as the natural log of the variance of returns over the period $-30,0$, averaged over each calendar month. $M V$ is the natural log of the firms market capitalization averaged for the calendar month. . CROSS is a dummy variable that equals 1 for those months in which a firm is cross-listed on another exchange. POST is a dummy variable that equals 1 for all firm-months from December 2002 onwards. $D Y$ is defined as the monthly average of the annualised dividend yield.

\section{Dividend Yield}

Dividend yield has been used in a number of studies to examine the impact of market changes on the cost of capital. While the cost of capital is difficult to estimate papers have shown that dividend yield and cost of capital are closely related. Bekaert and Harvey (2000) discuss the theory behind this relationship and conclude that dividend yield is an easily observable and stationary variable. It, therefore, is an excellent proxy for viewing the effect of dramatic structural changes on the market. Bhattachraya and Daouk (2002) in applying this model note that it is possibly better suited to examining the effect of insider trading laws introduction than market liberalisation, the purpose of the Bekaert and Harvey (2000) study. They conclude that the major weakness of the dividend yield measure, is that the dividend growth rate must be stationary. This is more likely to be true for changes in insider trading laws as it has no real impact on the company's growth rate. 


\begin{tabular}{|c|c|c|c|c|c|}
\hline \multicolumn{6}{|c|}{$\begin{array}{l}\text { Panel A: Difference in Mean Dividend Yield } \\
\end{array}$} \\
\hline & Mean & T-Stat & $p$-values & Wilcoxon & $p$-values \\
\hline \multicolumn{6}{|c|}{ Pre Regulation Change } \\
\hline 1996 & 0.0557 & -2.2333 & 0.0286 & -2.0230 & 0.0215 \\
\hline 1997 & 0.0626 & -2.7362 & 0.0078 & -3.1026 & 0.0010 \\
\hline 1998 & 0.0753 & -3.8812 & 0.0002 & -5.4245 & 0.0000 \\
\hline 1999 & 0.0654 & -2.9147 & 0.0047 & -3.7278 & 0.0001 \\
\hline 2000 & 0.0609 & -2.9536 & 0.0042 & -3.8554 & 0.0001 \\
\hline 2001 & 0.0588 & -2.6656 & 0.0094 & -3.1682 & 0.0008 \\
\hline \multicolumn{6}{|l|}{ Change Period } \\
\hline 2002 & 0.0527 & -1.6933 & 0.0946 & -1.9385 & 0.0263 \\
\hline \multicolumn{6}{|l|}{ Post Change } \\
\hline Post & 0.0323 & & & & \\
\hline
\end{tabular}

Panel B: Panel Regression Results

\begin{tabular}{|c|c|c|c|c|c|c|c|c|}
\hline & Model 1 & & Model 2 & & Model 3 & & Model 4 & \\
\hline Post & $\begin{array}{c}-0.0276 \\
(0.0015)\end{array}$ & **** & $\begin{array}{c}-0.0071 \\
(0.0012)\end{array}$ & *** & $\begin{array}{c}-0.0272 \\
(0.0015)\end{array}$ & $* * *$ & $\begin{array}{c}-0.0069 \\
(0.0012)\end{array}$ & $* * *$ \\
\hline MV & & & & & $\begin{array}{c}-0.0069 \\
(0.0010)\end{array}$ & *** & $\begin{array}{c}-0.0091 \\
(0.0016)\end{array}$ & $* * *$ \\
\hline CROSS & & & & & $\begin{array}{l}0.0100 \\
(0.0034)\end{array}$ & *** & $\begin{array}{c}-0.0003 \\
(0.0062)\end{array}$ & \\
\hline $\operatorname{AR}(1)$ & & & $\begin{array}{l}0.9367 \\
(0.0045)\end{array}$ & $* * *$ & & & $\begin{array}{l}0.9364 \\
(0.0046)\end{array}$ & $* * *$ \\
\hline R-Squared & 0.8521 & & 0.9778 & & 0.8532 & & 0.9778 & \\
\hline Durbin-Watson Statistic & 0.1616 & & 1.9370 & & 0.1621 & & 1.9420 & \\
\hline
\end{tabular}

Table 3: Impact of Regulatory Change on Dividend Yield

Note: ${ }^{* * *}$ Significant at $1 \%,{ }^{* *}$ Significant at $5 \%,{ }^{*}$ Significant at $10 \%$

Standard errors are shown in parentheses. The sample consists of 8330 firm months observations. All yearly means were calculated as calendar years with the exception of the post change period where the sample ran from April 2003 to March 2004. T-Stats were calculated using the matched pairs t-test. The dependent variable in all models is $D Y$ defined as the monthly average of the annualised dividend yield. Post is a dummy variable that equals 1 for firm months after December 2003, the time of the regulatory change. $M V$ is the natural log of the firms market capitalization averaged for the calendar month. CROSS is a dummy variable that equals 1 for those months in which a firm is cross-listed on another exchange. $A R(1)$ is an autoregressive term of which the coefficient is fixed across crosssectional units.

The results in Table 3 provide strong support for the hypothesis that the law change resulted in a substantial decrease in dividend yields. Panel A reports the test results of the mean level of $D Y$ before the change with the average after the change. As can be seen the average has decreased from between .055 to .0753 before the change period to just .0323 afterwards. This decrease is significant at the $1 \%$ level based on both the matched pairs t-test and the Wilcoxon signed rank tests in all 
periods except for 1996 where it is significant at the $5 \%$ level. It is also interesting to note that based on both the mean and the t-statistic there appears to be some preemption of the change. For the 2002 period there appears to be a decrease in the mean dividend yield with a resulting decrease in the significance of the differences between the 2002 period and the post period.

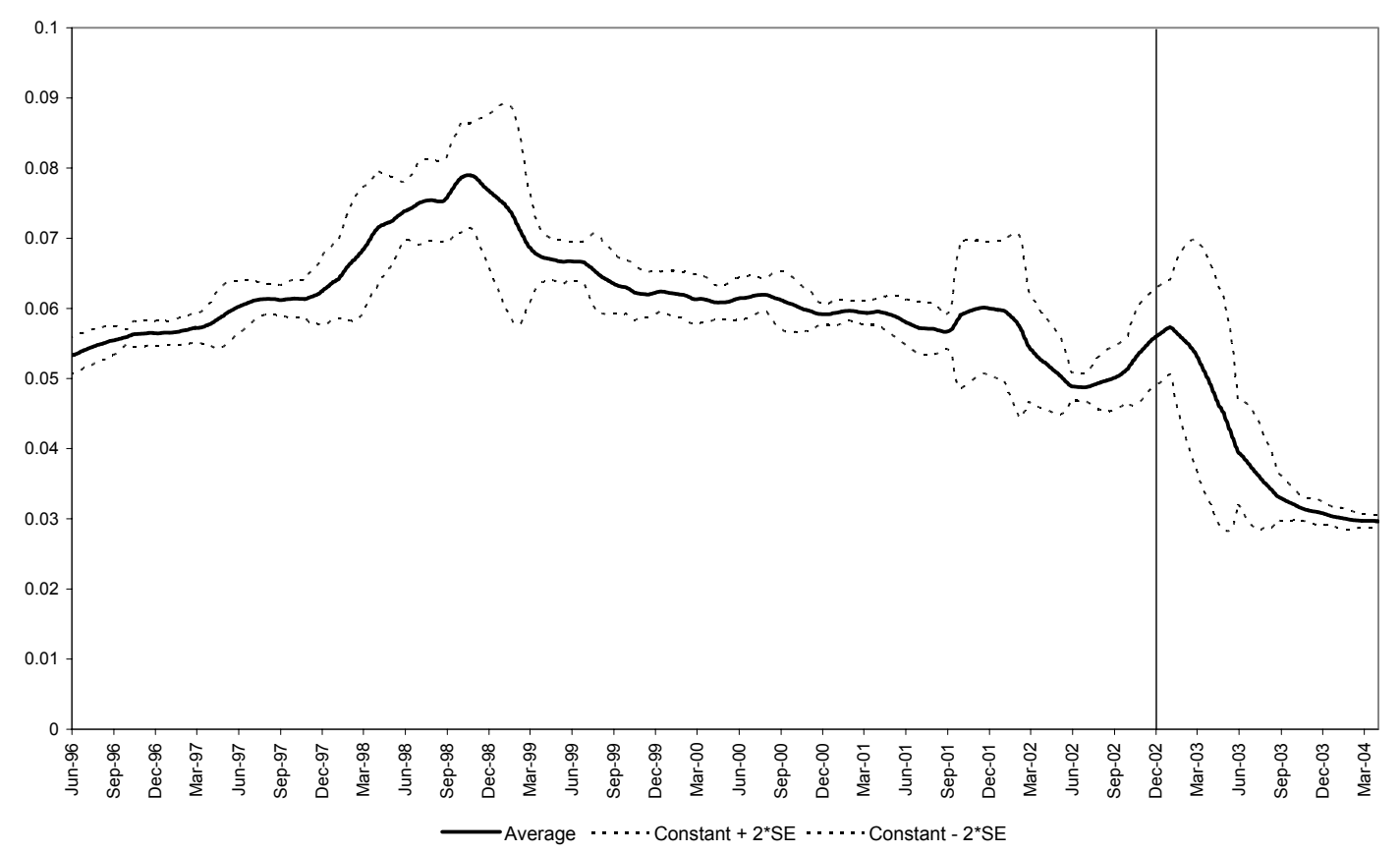

Figure 1: Rolling Regressions of Dividend Yield against a Constant

Note- The vertical axis represents the estimate from a regression run on the previous 100 daily dividend yield averaged over 85 companies against a constant. The dividend yield is defined as the annualised dividend yield. The vertical line represents the date the new legislation came into force.

This pre-emption is to a certain extent supported by the rolling regressions presented in Figure 1. There is a decrease in the average dividend yield starting at approximately December 2001, however it reverses and starts to increase about the middle of 2002. The graph shows more vividly the significant impact on dividend yield once the new law came into force on the $1^{\text {st }}$ December 2002 (represented by the vertical line). After that date we see a very sharp and rapid decrease before $D Y$ settles at a new stable level after October 2003. This indicates there was a sharp adjustment in the cost of capital brought about by the increase in the expected cost of insider trading. 
The panel regression results presented in Table 3 Panel $B$ also reject the hypothesis of no impact on the dividend yield from the regulatory change. The results show that the dummy variable for all months following the change period, POST, is significant at the $1 \%$ level in the four regression models employed. After controlling for autocorrelation by introducing an autoregressive term the relationship between POST and $D Y$ still remains strong. The regressions in Models 3 and 4 also include several control variables that may have impacted on the relationship. As can be seen the $M V$ variable is also captures a significant proportion of the variation in $D Y$ while the CROSS variable is only relevant when the $A R(1)$ is omitted from the regression. Controlling for both firm size and cross listings has little impact on the significance of the POST variable. The model also captures a significant proportion of the variation in dividend yield with an adjusted $R^{2}$ of .97 in Models 2 and 4 .

The results of the testing strongly support the view that the $D Y$ has decreased significantly as a result of the introduction of new insider trading laws. The average mean, according to both parametric and non-parametric tests has decreased markedly. Figure 1 employing rolling regressions shows that the change occurred soon after the introduction of the new laws and finally the panel regressions revealed a very strong decline in DY after the law change. This indicates that there was a dramatic structural change in the cost of capital of New Zealand firms following the date that the new laws came into effect.

\section{Bid Ask Spreads}

Several papers have developed theoretical models that make predictions about the effect insider trading has on the bid ask spread. Copeland and Galai (1988), Glosten and Milgrom (1985) and Kyle (1985) have all predicted a positive relationship between the prevalence of insider trading and the spreads that market makers set. This has also been supported by Chung and Charoenwong (1998) empirically who found that market makers, although not able to spot exactly when an insider trades, set greater spreads on firms with a greater incidence of insider trading to compensate for their losses to informed traders in the long run. The recent law changes in New Zealand should have raised the cost of insider trading and resulted in a reduction of the incidence as insiders trade less. As such and in line with both 
the theoretical and empirical evidence we would expect to see a significant decrease in the spreads on companies in the New Zealand market.

Table 4 presents the results for the tests on the bid ask spreads. As can be observed in Panel A there is strong evidence of a significant decrease in the level of the spreads in the post change periods. The mean bid ask spreads declined from an average of $3.95 \%(-3.23)$ to $2.65 \%(-3.63)$ to a post change mean of $2.23 \%(-3.79)$. The difference in means is significant at the 1\% level from 1998 onwards including the change period of 2002, with 1996 at the 5\% level and 1997 at $10 \%$. These significance levels are also repeated for the Wilcoxon test values with only 1996 and 1997 having $p$-values above the 1\% level. Figure 2 also supports the notion of the impact of the regulatory change. The rolling regressions show an immediate decrease following the new regime commencing. The graph also shows that the decline in spreads appears to be slowing down after having dropped to its lowest point observed over the sample period.

Panel B of Table 4 presents the panel regression results for the spreads. The coefficient estimates also support the belief that there has been a decrease in the spreads following the introduction of the new laws. The POST variable is significant in all specifications at the $1 \%$ level. $M V$ has a very strong association with the spreads in all the models supporting the cross correlations presented in Table 2. Again the results show that CROSS is only relevant when the $A R(1)$ term is excluded. The same is true of the VAR and $V O L$ measures which were included to control for the liquidity and volatility determinants of the spreads. Both these variables are important before the model is adjusted to account for serial correlation of the residuals although they do appear to have an effect due to the much reduced significance level when both they and the $A R(1)$ term are included together. Again the adjusted $\mathrm{R}^{2}$ suggests that the models fit the data well. The results therefore all point to a significant decrease in the spreads following the regulatory amendments. 


\begin{tabular}{|c|c|c|c|c|c|c|c|c|c|c|c|c|}
\hline \multicolumn{13}{|c|}{ Panel A: Differences in Mean Bid Ask Spreads } \\
\hline & Mean & & T-Stat & & $p$-values & & Wilcoxon & & $p$-values & & & \\
\hline \multicolumn{13}{|l|}{ Pre Regulation Change } \\
\hline 1996 & -3.6027 & & -2.2546 & & 0.0268 & & -2.0529 & & 0.0200 & & & \\
\hline 1997 & -3.6315 & & -1.9456 & & 0.0551 & & -1.4920 & & 0.0679 & & & \\
\hline 1998 & -3.2308 & & -7.9399 & & 0.0000 & & -6.3061 & & 0.0000 & & & \\
\hline 1999 & -3.5099 & & -4.3871 & & 0.0000 & & -4.5713 & & 0.0000 & & & \\
\hline 2000 & -3.4984 & & -3.9294 & & 0.0002 & & -4.3081 & & 0.0000 & & & \\
\hline 2001 & -3.4544 & & -5.7297 & & 0.0000 & & -5.4855 & & 0.0000 & & & \\
\hline \multicolumn{13}{|l|}{ Change Period } \\
\hline 2002 & -3.5180 & & -5.2523 & & 0.0000 & & -5.5881 & & 0.0000 & & & \\
\hline \multicolumn{13}{|l|}{ Post Change } \\
\hline Post & -3.7943 & & & & & & & & & & & \\
\hline \multicolumn{13}{|c|}{ Panel B: Panel Regression Results } \\
\hline & Model 1 & & Model 2 & & Model 3 & & Model 4 & & Model 5 & & Model 6 & \\
\hline \multirow[t]{2}{*}{ Post } & -0.2334 & $* * *$ & -0.1742 & $* * *$ & -0.2021 & $* * *$ & -0.1588 & $* * *$ & -0.2019 & $* * *$ & -0.1590 & **** \\
\hline & $(0.0153)$ & & $(0.0284)$ & & $(0.0144)$ & & $(0.0266)$ & & $(0.0145)$ & & $(0.0267)$ & \\
\hline \multirow[t]{2}{*}{ MV } & & & & & -0.3640 & $* * *$ & -0.4320 & $* * *$ & -0.3619 & $* * *$ & -0.4321 & *** \\
\hline & & & & & $(0.0104)$ & & $(0.0211)$ & & $(0.0105)$ & & $(0.0211)$ & \\
\hline \multirow[t]{2}{*}{ CROSS } & & & & & 0.0742 & $* *$ & 0.0178 & & 0.0713 & $* *$ & 0.0176 & \\
\hline & & & & & $(0.0357)$ & & $(0.0769)$ & & $(0.0357)$ & & $(0.0769)$ & \\
\hline \multirow[t]{2}{*}{ VAR } & & & & & & & & & 0.0089 & $* *$ & 0.0025 & \\
\hline & & & & & & & & & $(0.0043)$ & & $(0.0037)$ & \\
\hline \multirow[t]{2}{*}{ VOL } & & & & & & & & & -11.6351 & $* * *$ & 0.4398 & \\
\hline & & & & & & & & & $(3.8185)$ & & (2.4349) & \\
\hline \multirow[t]{2}{*}{$\operatorname{AR}(1)$} & & & 0.7658 & $* * *$ & & & 0.7416 & $* * *$ & & & 0.7416 & $* * *$ \\
\hline & & & $(0.0071)$ & & & & $(0.0074)$ & & & & $(0.0074)$ & \\
\hline R-Squared & 0.8081 & & 0.9201 & & 0.8325 & & 0.9238 & & 0.8327 & & 0.9238 & \\
\hline Durbin-Watson Statistic & 0.4715 & & 2.2872 & & 0.5230 & & 2.2941 & & 0.5260 & & 2.2949 & \\
\hline
\end{tabular}

Table 4: Impact of Regulatory Changes on Bid Ask Spreads

Note: *** Significant at $1 \%,{ }^{* *}$ Significant at $5 \%,{ }^{*}$ Significant at $10 \%$

Standard errors are shown in parentheses. The sample consists of 8330 firm months observations. All yearly means were calculated as calendar years with the exception of the post change period where the sample ran from April 2003 to March 2004. T-Stats were calculated using the matched pairs t-test. The dependent variable in all models is $B A$ defined as the natural log of the monthly average of the daily ask price minus the bid price divided by the midpoint of the spreads. Post is a dummy variable that equals 1 for firm months after December 2003, the time of the regulatory change. MV is the natural log of the firms market capitalization averaged for the calendar month. CROSS is a dummy variable that equals 1 for those months in which a firm is cross-listed on another exchange. VAR represents the return volatility of the firm and is defined as the natural log of the variance of returns over the period $-30,0$, averaged over each calendar month. VOL represents the firms liquidity and is defined as the monthly average of the daily dollar value of trading divided by the market value of the company. $A R(1)$ is an autoregressive term where the coefficient is fixed across cross-sectional units. 


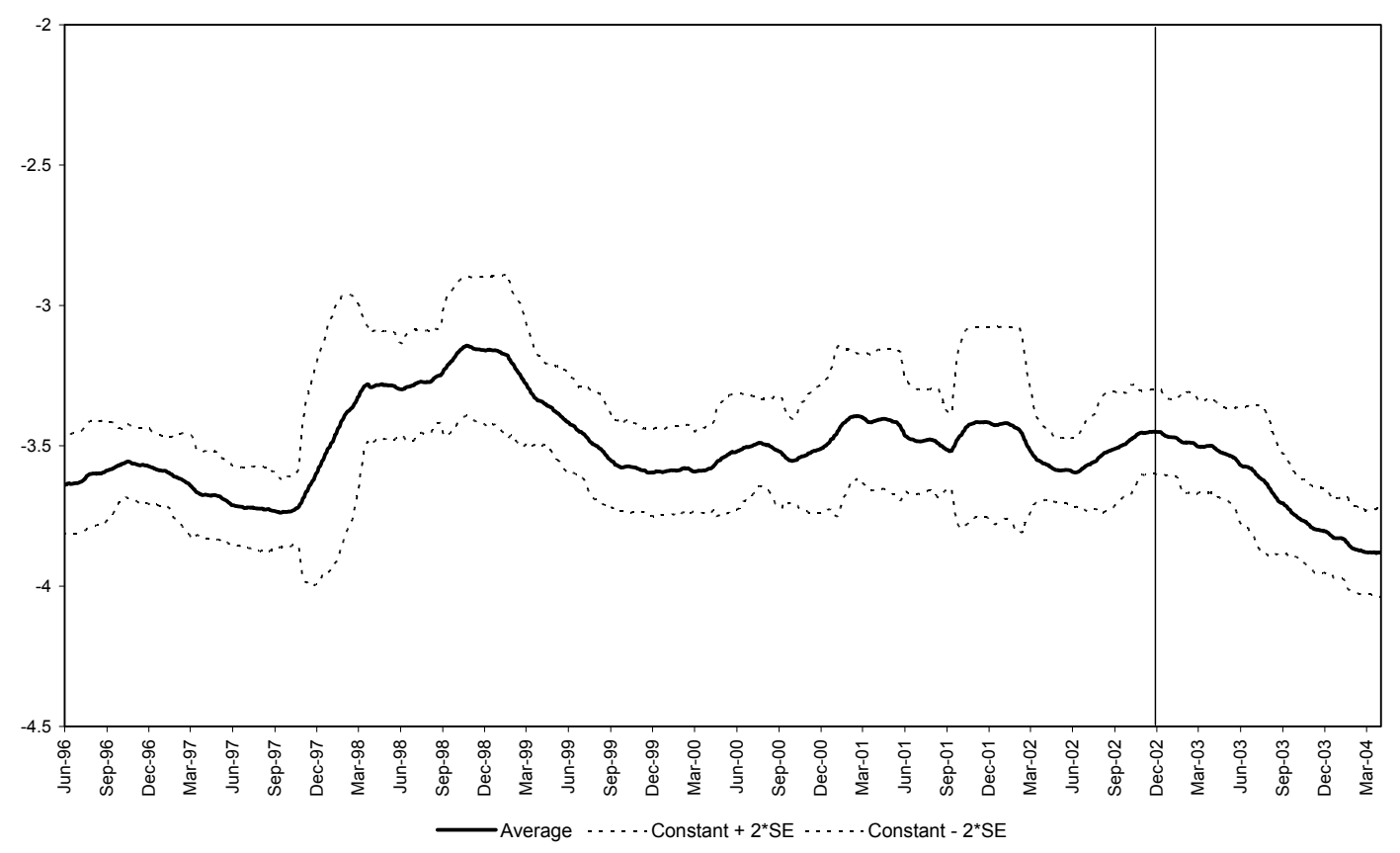

Figure 2: Rolling Regressions of the Bid Ask Spread against a Constant

Note- The vertical axis represents the estimate from a regression run on the previous 100 daily bid ask spreads averaged over 85 companies against a constant. The daily bid ask spread is defined as the natural logarithm of the bid price minus the ask price divided by the midpoint of the spreads. The vertical line represents the date the new legislation came into force.

\section{Liquidity}

Ausbel (1990) built on the earlier models of insider trading by trying to quantify the impact of insider trading on investor confidence. One of the conclusions she makes, in line with the models of Kyle (1985) Glosten and Milgrom (1985) and Copeland and Galai (1988), is that loss of investor confidence impacts negatively on the liquidity in a market. Investors feeling uncertain about their prospects of getting a fair deal are put off the market and reduce their investment in the market. This finding was also supported by the model of Fishman and Hagerty (1995) who concluded that insider trading harms outsiders which results in investors withdrawing from the market. As discussed above, the new laws should result in less insider trading as they trade only when their information will compensate for the increased cost of insider trading. As a result the liquidity of the sample firms should increase following the new laws introduction. 
Panel A of Table 5 presents the results for liquidity. As can be seen the results strongly support an increase in liquidity following the introduction of the Securities Market Amendment Act 2002. The average of the sample has increased from around $.08 \%$ of the firms value traded per day, to $.12 \%$, a marked increase and nearly double the change period. The increase in liquidity is also significant across the board at the $5 \%$ level or better in all years. The only exception to this is the Wilcoxon signed rank test value for 1996 which has a $p$-value of .11. The rolling regressions in Figure 3 again strongly support this finding with an almost immediate increase following the introduction of the new law to a higher level than is observed at any point in the pre change period. The increase is relatively sharp with the new level being reached by June 2003.

Panel B Table 5 also provides evidence to support the notion that the legislative changes have had an impact on insider trading. In all four model specifications the POST variable is positive and significant at the $1 \%$ level. Due to the use of market capitalisation as a denominator in the construction of the liquidity variable, $M V$ was excluded from the regressions to avoid spurious relationships induced by the variable construction. We include $B A$ instead due to the impact that spreads have on liquidity. The results show that CROSS somewhat surprisingly has no impact on the volume traded, although $B A$ is significant in both Models 3 and 4 , although only at the $10 \%$ level in Model 4 . The adjusted $R^{2}$ shows that while the models are not as strong as those for dividend yield and bid ask spread, the model does appear to explain a reasonable amount of the variation in the liquidity. The results overall provide strong evidence that liquidity in the sample firms increased in the period following the introduction of the new insider trading laws. 


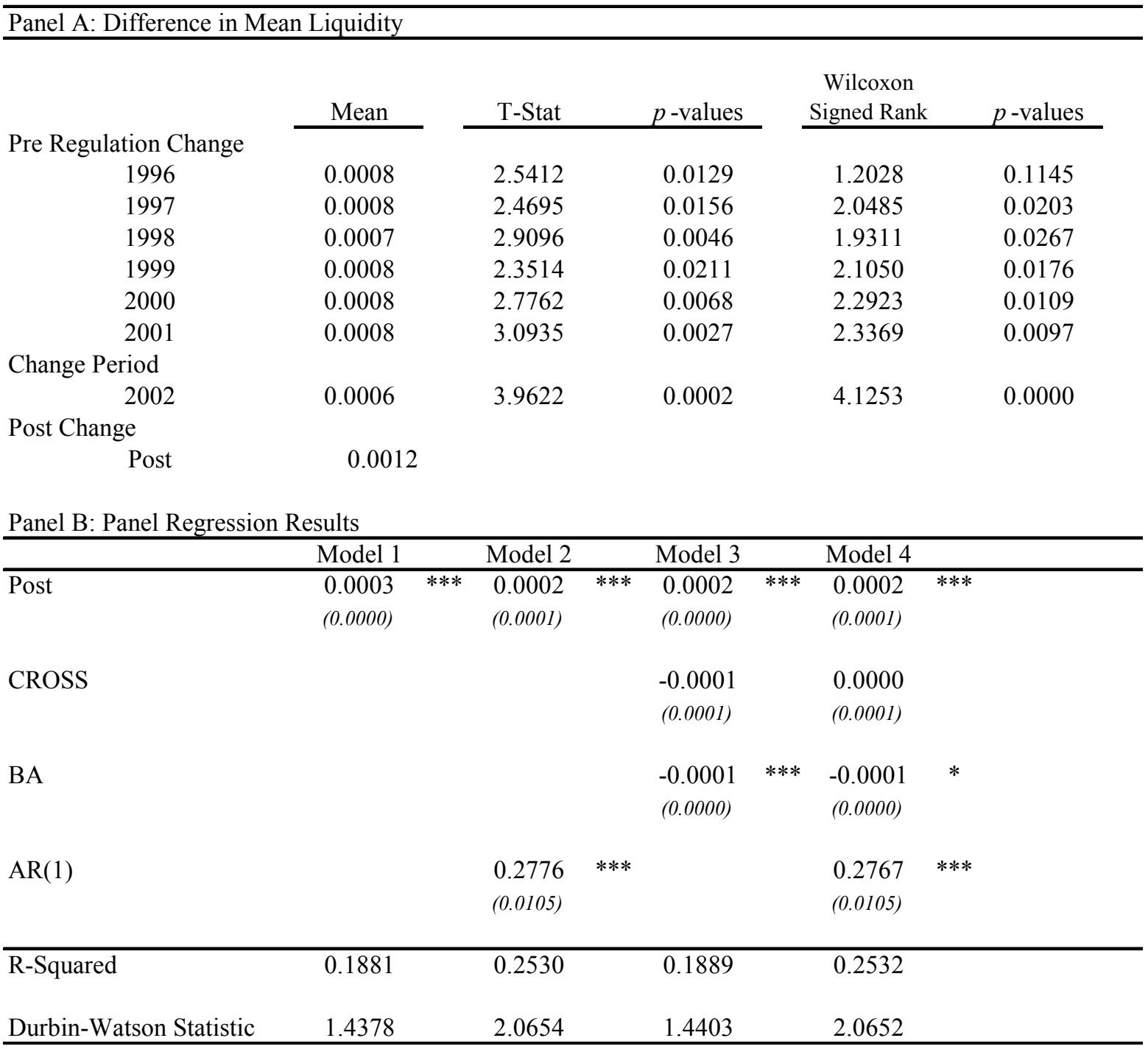

Table 5: Impact of Regulatory Change on Liquidity

Note: ${ }^{* * *}$ Significant at $1 \%,{ }^{* *}$ Significant at $5 \%,{ }^{*}$ Significant at $10 \%$

Standard errors are shown in parentheses. The sample consists of 8330 firm months observations. All yearly means were calculated as calendar years with the exception of the post change period where the sample ran from April 2003 to March 2004. T-Stats were calculated using the matched pairs t-test. The dependent variable in all models is $V O L$ defined as the monthly average of the daily dollar value of trading divided by the market value of the company. Post is a dummy variable that equals 1 for firm months after December 2003, the time of the regulatory change. CROSS is a dummy variable that equals 1 for those months in which a firm is cross-listed on another exchange. BA defined as the natural log of the monthly average of the daily ask price minus the bid price divided by the midpoint of the spreads $A R(1)$ is an autoregressive term where the coefficient is fixed across cross-sectional units. 


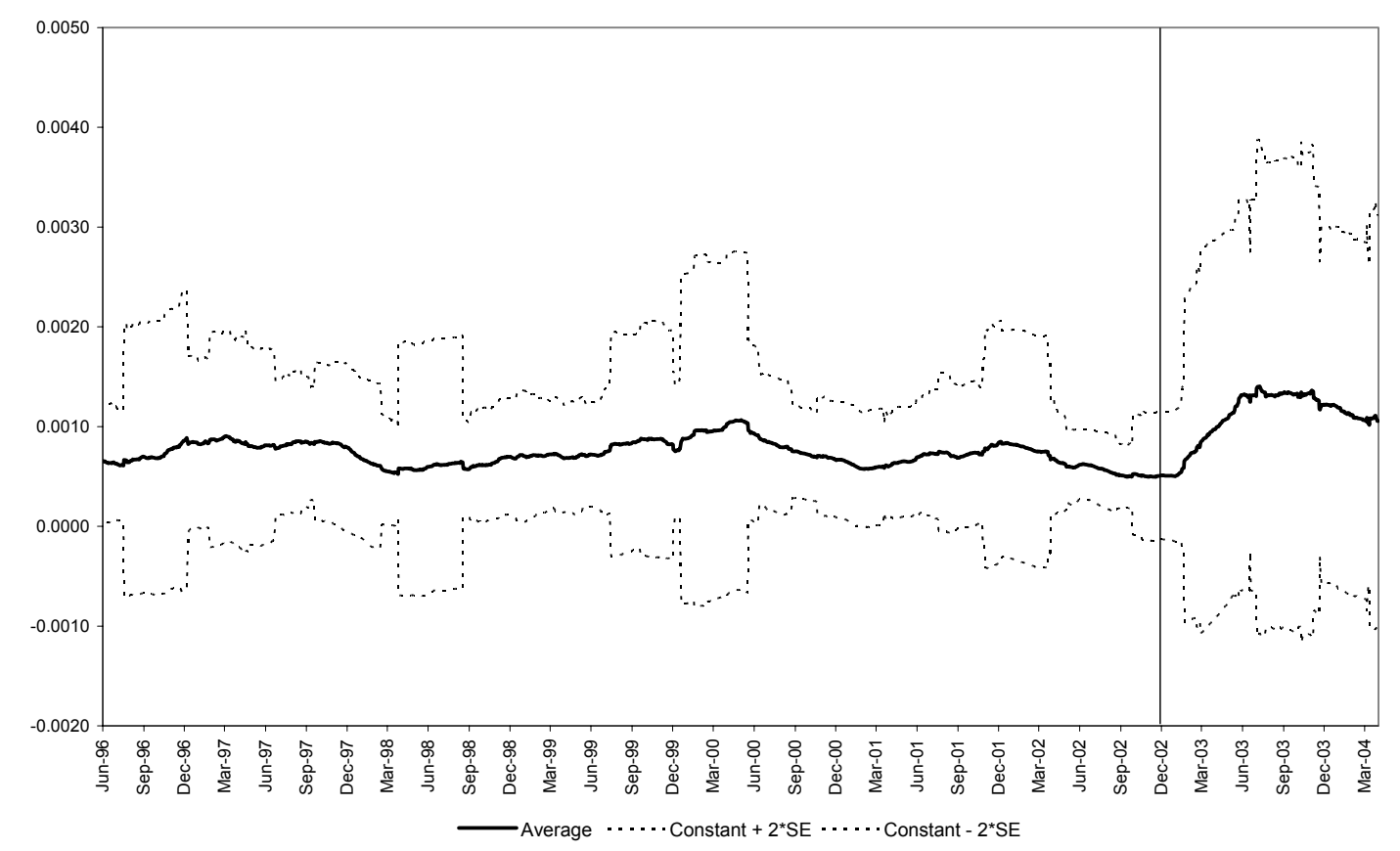

Figure 3: Rolling Regressions of Liquidity against a Constant

Note- The vertical axis represents the estimate from a regression run on the previous 100 daily liquidity averaged over 85 companies against a constant. The liquidity is defined as the dollar value of trading divided by the current market capitalisation. The vertical line represents the date the new legislation came into force.

\section{Volatility}

The final measure examined is volatility. Kyle (1985) argued that insider trading reduced the depth of a market making stocks more prone to price shocks and increased volatility. Therefore, another sign of an improvement in the market brought about by a reduction in insider trading would be a significant decrease in the volatility of the market.

Panel A of Table 6 presents the mean volatility before and after the law change. The results support the belief that the volatility of shares has decreased compared with all years except 1996. While 1996 for both the t-test and the Wilcoxon signed rank test is insignificant, every other year is significant, in all but 1997 at the $1 \%$ level. There also appears to be a similar pre-emption to that observed in the dividend yield with the mean for 2002 being larger than those in the pre change period and the significance down to the $10 \%$ level for the t-test. The pattern depicted in Figure 4 is also consistent with the decrease in volatility occurring during a u shape dip in volatility that climbs back up before the date the new regime came into effect. 
Once the new law is enacted there is a significant and sharp decrease in the volatility.

\begin{tabular}{|c|c|c|c|c|c|c|c|c|c|}
\hline \multicolumn{10}{|c|}{ Panel A: Differences in the Return Volatility Means } \\
\hline & Mean & & T-Stat & & $p$-values & & Wilcoxon & & $p$-values \\
\hline \multicolumn{10}{|l|}{ Pre Regulation Change } \\
\hline 1996 & -8.2281 & & 1.1959 & & 0.2351 & & -0.2631 & & 0.3962 \\
\hline 1997 & -8.0981 & & 2.3293 & & 0.0222 & & 1.7461 & & 0.0404 \\
\hline 1998 & -7.6468 & & 6.9550 & & 0.0000 & & 5.6104 & & 0.0000 \\
\hline 1999 & -7.9400 & & 3.6478 & & 0.0005 & & 4.2178 & & 0.0000 \\
\hline 2000 & -7.7784 & & 6.2686 & & 0.0000 & & 5.1349 & & 0.0000 \\
\hline 2001 & -7.8299 & & 5.0419 & & 0.0000 & & 4.5176 & & 0.0000 \\
\hline \multicolumn{10}{|l|}{ Change Period } \\
\hline 2002 & -8.1669 & & 1.7179 & & 0.0895 & & 1.9347 & & 0.0265 \\
\hline \multicolumn{10}{|l|}{ Post Change } \\
\hline Post & -8.3935 & & & & & & & & \\
\hline \multicolumn{10}{|c|}{ Panel B: Panel Regression Results } \\
\hline & Model 1 & & Model 2 & & Model 3 & & Model 4 & & \\
\hline \multirow[t]{2}{*}{ Post } & -0.2968 & $* * *$ & -0.1618 & $* *$ & -0.3101 & $* * *$ & -0.1647 & $* *$ & \\
\hline & $(0.0363)$ & & $(0.0644)$ & & $(0.0365)$ & & $(0.0646)$ & & \\
\hline \multirow[t]{2}{*}{ MV } & & & & & -0.2172 & $* * *$ & -0.0735 & & \\
\hline & & & & & $(0.0265)$ & & $(0.0500)$ & & \\
\hline \multirow[t]{2}{*}{ CROSS } & & & & & 0.1476 & & 0.1027 & & \\
\hline & & & & & $(0.0906)$ & & $(0.1765)$ & & \\
\hline \multirow[t]{2}{*}{$\operatorname{AR}(1)$} & & & 0.6383 & $* * *$ & & & 0.6363 & $* * *$ & \\
\hline & & & $(0.0085)$ & & & & $(0.0085)$ & & \\
\hline R-Squared & 0.4640 & & 0.6814 & & 0.4683 & & 0.6814 & & \\
\hline Durbin-Watson Statistic & 0.7269 & & 1.8675 & & 0.7352 & & 1.8662 & & \\
\hline
\end{tabular}

Table 6: Impact of Regulatory Changes on Return Volatility

Note: *** Significant at $1 \%,{ }^{* *}$ Significant at $5 \%,{ }^{*}$ Significant at $10 \%$

Standard errors are shown in parentheses. The sample consists of 8330 firm months observations. All yearly means were calculated as calendar years with the exception of the post change period where the sample ran from April 2003 to March 2004. T-Stats were calculated using the matched pairs t-test. The dependent variable in all models is VAR defined as the natural log of the variance of returns over the period $-30,0$, averaged over each calendar month. Post is a dummy variable that equals 1 for firm months after December 2003, the time of the regulatory change. MV is the natural log of the firms market capitalization averaged for the calendar month. CROSS is a dummy variable that equals 1 for those months in which a firm is cross-listed on another exchange. $A R(1)$ is an autoregressive term where the coefficient is fixed across cross-sectional units.

The panel regressions in Panel B of Table 6 also provide firm support for the impact of regulatory change. There is a strong negative association between $V O L$ and POST. The relationship does however weaken when serial correlation in the errors is controlled for. The results also show that the negative and significant 
relationship between $V A R$ and $M V$ disappears when the autoregressive term is included. This is in contrast to dividend yields and the spreads where the $M V$ retained its significance. The results also show no connection between volatility and CROSS which supports the cross correlations presented in Table 2. Again the model specifications used result in strong $\mathrm{R}^{2}$ values with values between .46 and .68, suggesting that the models are explaining a sizeable portion of the variation in the volatility in the sample. The results as a whole suggest that volatility has decreased with the introduction of the new laws.

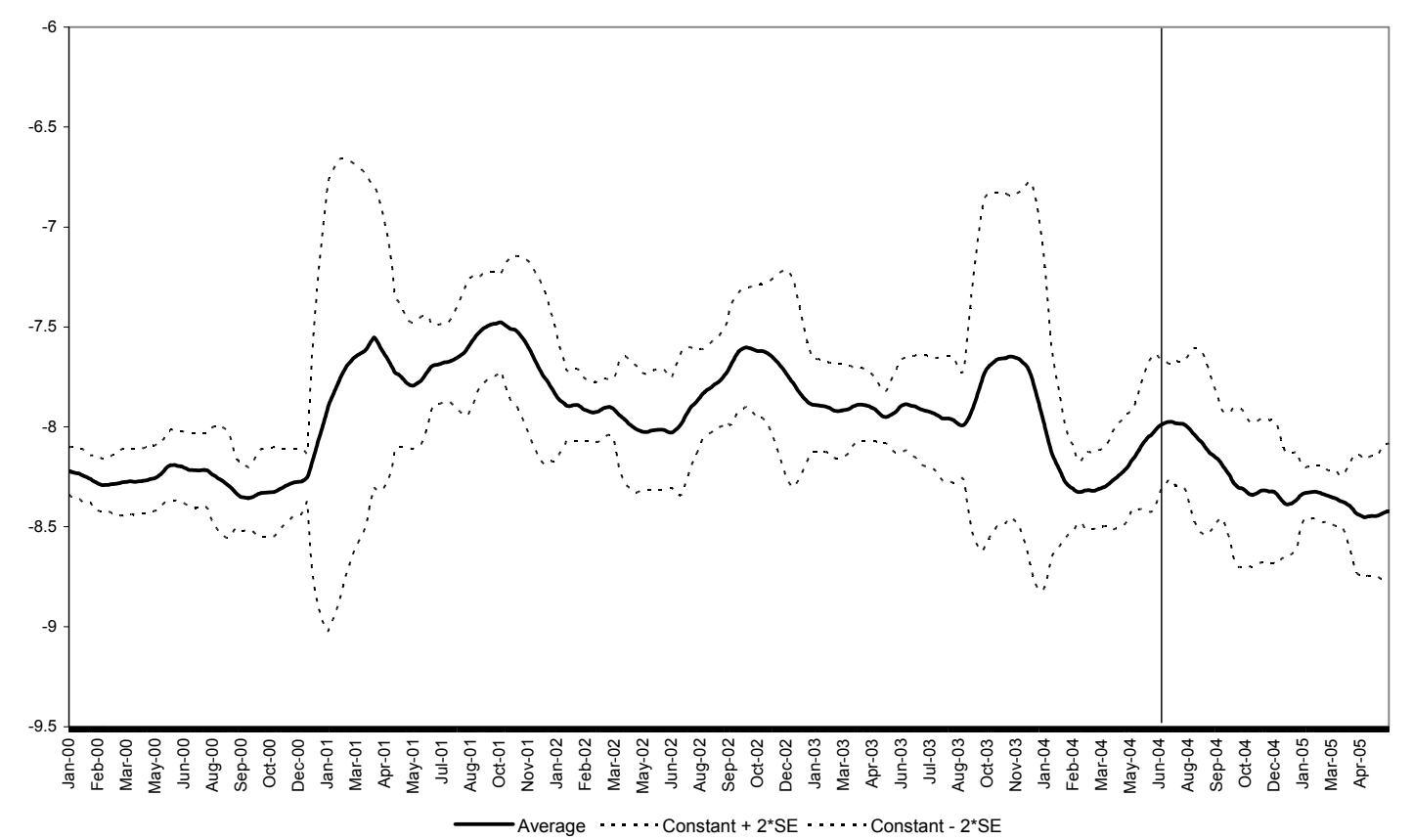

Figure 4: Rolling Regressions of Share Volatility against a Constant

Note- The vertical axis represents the estimate from a regression run on the previous 100 day's share volatility averaged over 85 companies against a constant. The share volatility was defined as the natural log of the variance in returns over the previous 30 days. The vertical line represents the date the new legislation came into force.

The results for all four measures show strong support for the contention that the introduction of the new law has resulted in a marked change in the structure of the market. Dividend yields, bid ask spreads and volatility have all seen substantial decreases in the average level since the change in regulations while the liquidity has significantly increased. For all measures the change can be shown to have occurred on or very soon after the change in the laws supporting the view that the structural change has occurred as a result of the change in the insider trading laws. The results 
also show that even controlling for other known determinants of the measures employed the dummy variable for the post change period, POST, is significant in all cases, at the $1 \%$ level in most model specifications. The models used also show high $R^{2}$ values especially for the dividend yield and bid ask spreads suggesting an extremely good fit. The new laws appear to have been effective in increasing the cost of insider trading and lowering its incidence and therefore the harm that it causes to the market microstructure.

\section{CONCLUSIONS}

This paper set out to examine whether the new insider trading laws in New Zealand have resulted in the expected improvements in the market as a result of the hypothesised reduction in the incidence of insider trading. This was achieved by comparing four variables that have been shown to be impacted by insider trading. The variables examined were the dividend yield which was used to proxy for the cost of capital, the natural log of the bid-ask spread, liquidity measured as the daily percentage of the firm's market capitalisation traded and finally the natural log of the volatility. If the new laws have had the expected effect you should see reductions in the cost of capital, spreads and return volatility accompanied by an increase in the liquidity. Our results provide strong support for the notion that the new regulatory regime has had a positive impact on the market, as well as adding to the evidence that regulations do have a role in protecting the market from insiders. For all the variables a significant change in the average level of the variables was observed after the introduction of the new laws. The results overall provided strong evidence that the regulatory changes have resulted in a significant reduction of the microstructure effects of insider trading.

Several questions remain that should be the subject of future research. The first is the impact of the enforcement actions on the changes that have been observed following the introduction of the Securities Market Amendment Act 2002. In particular, it appears that the lack of confidence in the previous regime was a consequence of failed prosecutions in the early 1990's and the lack of successful prosecutions over its entire life. It would therefore be interesting to observe the markets reaction to any future prosecutions to see whether the changes become 
cemented or are undone by their success or failure. Further research is needed to see the effects of insider trading in New Zealand stack up with other regulated markets. While the results show a significant improvement, they provide no insight into whether the current legal structure is the most effective one available. 


\section{Endnotes}

1. The profitability of self-reported insider transactions has been examined in the U.S. (Finnerty, 1976; Seyhun, 1986; Lakonishok and Lee, 2001), Canada (Baesel and Stein, 1979) Spain (Del Brio, Miguel and Perote, 2002), Poland (Wisniewski and Bohl, 2004), New Zealand (Eterbari, Tourani-Rad and Gilbert, 2003) and U.K. (Pope et al., 1990; Friederich et al., 2002).

2. These were the cases of Colonial Mutual Life Assurance Society Ltd v Wilson Neill Ltd [1994] MCLR 134 and Kincaid v Capital Markets Equities Ltd (1995) 1 ACSR 53. Both were cases attempting to force the respective companies to take an action against insiders under s18. In both cases the courts ruled the companies had good reason not to take the case and declined leave to force the companies to act.

3. Exchanges rates against the USD over this time for January of each year were 19961.5137 , 1997 1.4247, 1998 1.7283, 1999 1.8545, 2000 1.9451, 2001 2.2502, 20022.35512003 1.8505 and 20041.4863. 


\section{REFERENCES}

Acker, D., Stalker, M., \& Tonks, I. (2002), "Daily Closing Inside Spreads and Trading Volumes around Earnings Announcements", Journal of Business Finance and Accounting 29, 1149-1180.

Ausbel , L. (1990), "Insider Trading in a Rational Expectations Economy", American Economic Review 80, 1022-1039.

Baesel, J., \& G. Stein (1979), "The Value of Information: Inferences from the Profitability of Insider Trading", Journal of Financial and Quantitative Analysis $14,553-571$.

Banerjee, A., \& Eckard, E. (2001), "Why Regulate Insider Trading? Evidence from the First Great Merger Wave (1897-1903)", American Economic Review 91, 1327-1349.

Bekaert, G., \& Harvey, C. (2000), "Foreign Speculators and Emerging Equity Markets". Journal of Finance 45, 565-613.

Bernhardt, D., Hollifield, B., \& Hughson, E. (1995), "Investment and Insider Trading", Review of Financial Studies 8, 501-543.

Bhattacharya, U., \& H. Daouk (2002), "The World Price of Insider Trading", Journal of Finance 57(1), 75-108.

Bushman, R., Piotroski, J., \& A. Smith (2003), "Insider Trading Restrictions and Analysts' Incentives to Follow Firms", SSRN Working Paper.

Chamberlain, G. (1978), "Omitted Variable Bias is Panel Data: Estimating the Returns to Schooling", An-nales de L'Insee 30/31, 49-82.

Chung, K and Charoenwong C. (1998), "Insider Trading and Bid-Ask Spread", The Financial Review 33, 1-20.

Copeland, T., \& Galai, D. (1988), "Information Effects and the Bid-Ask Spread", Journal of Finance 38, 1457-1469.

Del Brio, E., Miguel, A., \& J. Perote (2002), "An Investigation of insider trading profits in the Spanish Stock Market", The Quarterly Review of Economics and Finance 42, 73-94.

Driffill, J., \& Sola, M. (1998), "Intrinsic Bubbles and Regime-Switching", Journal of Monetary Economics 42, 357-373.

Etebari, A., Tourani-Rad, A., and A. Gilbert (2003), "Disclosure Regulation and the Profitability of Insider Trading: Evidence from New Zealand", Pacific-Basin Finance Journal Forthcoming.

Finnerty, J. (1976), "Insiders and Market Efficiency", Journal of Finance 31, 11411148.

Fishman, M. and Hagerty, K. (1995), "The Mandatory Dislosure of Trades and Market Liquidity", The Review of Financial Studies 8, 637-676.

Friederich, S, Gregory, A, Matako, J and I. Tonks (2002), "Detecting Returns Around the Trades of Corporate Insiders in the London Stock Exchange", European Financial Management 8, 7-30.

Garfinkel, J. (1997), "New Evidence on the Effects of Federal Regulations on Insider Trading: The Insider Trading and Securities Fraud Enforcement Act (ITSFEA)", Journal of Corporate Finance 3, 89-111.

Gilbert, A., Tourani-Rad, A., \& Wisneiwski, T. P. (2004), „Do Insiders Crowd out Analysts?", Auckland University of Technology Working Paper. 
Glosten, L., \& Milgrom, P. (1985), "Bid, Ask and Transaction Prices in a Specialist Market with Heterogeneously Informed Traders", Journal of Financial Economics 14, 71-100

Hausman, J., \& Taylor, W. (1981), "Panel Data and Unobservable Individual Effects", Econometrica 49, 1377-1398.

Henry, P. (2000), "Stock Market Liberalisation, Economic Reform, and Emerging Market Equity Prices", Journal of Finance 45, 529-564

Huddart, S., Hughes, J., \& C. Levine (2001), "Public Disclosure and Dissimulation of Insider Trades", Econometrica 69, 665-681.

Jaffe, J. (1974), "The Effect of regulation Changes on Insider Trading", Bell Journal of Economics and Management Sciences 5, 93-121.

Jain, P. (2002), "Institutional Design and Liquidity at Stock Exchanges around the World", SSRN Working Paper.

Khanna, N., \& S. Slezak (1994), "Insider Trading, Outside Search and Resource Allocation: Why Firms and Society may Disagree on Insider Trading Restrictions", The Review of Financial Studies 7, 575-608.

Kyle, A. (1985), "Continuous Auctions and Insider Trading", Econometrica 53, 13151335

Lakonishok, J., \& I. Lee (2001), "Are Insiders Trades Informative?", The Review of Financial Studies 14, 79-111.

Leland, H. (1992), "Insider Trading: Should It Be Prohibited?", Journal of Political Economy 100, 859-887.

Manne, H. (1966), Insider Trading and the Stock Market. New York: The Free Press.

Noe, C. (1999), "Voluntary Disclosures and Insider Transactions", Journal of Accounting and Economics 27, 305-26.

Piotroski, J. and Roulstone, D. (2003), "Do Insider Trades Reflect Superior Knowledge About Future Cash Flow Realiations?", [Unpublished Paper]. University of Chicago.

Pope, P., Morris, R., and D. Peel (1990), "Insider Trading: Some Evidence on Market Efficiency and Directors Share Dealings in Great Britain", Journal of Business, Finance and Accounting 17, 359-380.

Repullo, R. (1999), "Some Remarks on Leland's Model of Insider Trading", Econometrica 66, 359-374.

Seyhun, N. (1986), "Insider Profits, Costs of Trading and Market Efficiency", Journal of Financial Economics 16, 189-212.

Seyhun, N. (1992), "The Effectiveness of Insider-Trading Sanctions", Journal of Law and Economics 35, 149-182.

Seyhun, N. (1998), Investment Intelligence from Insider Trading. Cambridge, MA: MIT Press.

Wisniewski, T.P., \& Bohl, M.T. (2004), "The Information Content of Registered Insider Trading under Lax Law Enforcement", forthcoming International Review of Law and Economics. 


\section{Faculty of Business Research Paper Series}

01-2003 SIMON MOWATT and HOWARD COX

02-2003

BILL DOOLIN, BOB MCQUEEN and MARK WATTON

03-2003 ROGER BAXTER and SHEELAGH MATEAR

04-2003 HOWARD COX and SIMON MOWATT

05-2003 CHRISTOPHER BOGGS, BRETT COLLINS and MARTIE-LOUISE VERREYNNE

06-2003 MARK GLYNN, JUDY MOTION and RODERICK BRODIE

07-2003 DERYL NORTHCOTT and LI-CHENG CHANG

08-2003 ROY SMOLLAN and JONATHAN MATHENY

09-2003 ROBIN H. LUO and L. CHRISTOPHER PLANTIER

10-2004 SIMON MOWATT

11-2004 HELEN ANDERSON and JONATHAN MATHENY
Innovation Networks and the Development of Consumer-Driven ICT-Based Management Systems

Internet Strategies for Established Retailers: Five Case Studies from New Zealand

Measuring Intangible Value in Business to Business Buyer-Seller Relationships: An Intellectual Capital Perspective

Technology, Organisation and Innovation: The Historical Development of the UK Magazine Industry

Examining the Effects of Referent Power on Intrinsic Motivation in Organisations: A SelfConcept Based Approach

Retailers' Perceived Value of Manufacturers' Brands

The Use of Performance Measurement as an Accountability Mechanism: A Case Study in the UK National Health Service

Emotions Experienced Through Organisational Events: An Exploratory Framework of Perceived Justice and Outcomes

The Persistence of NZ Dollar Misalignments Relative to Purchasing Power Parity

New Perspectives on the Supply-Chain and Consumer-Driven Innovation

Paying Attention To The Construct Of Salience In Identity-related Literature and Beyond 
12-2004 AARON GILBERT, AliREZA The Impact of Regulatory Change on Insider TOURANI-RAD and Trading Profitability: Some Early Evidence from TOMASZ WISNIEWSKI New Zealand

13-2004 AARON GILBERT, AliReZA Do Insiders Crowd Out Analysts? TOURANI-RAD and

TOMASZ WISNIEWSKI

14-2004 AARON GILBERT, AliREZA Insiders and the Law: The Impact of TOURANI-RAD and Regulatory Change on Insider Trading

TOMASZ WISNIEWSKI

15-2004 JULIE DOUgLAS

Wages and Conditions of Clinical Coders in New Zealand. A report of surveys conducted in 1998 and 2004 